\title{
Stakeholders Needs Requisite Analysis: Towards Croatian Marine Spatial Data Infrastructure Establishment
}

\author{
Marina TAVRA, Tea DUPLANČIĆ LEDER, Vlado CETL
}

\begin{abstract}
National Marine Spatial Data Infrastructure (MSDI) in the Republic of Croatia has not yet been implemented. This paper examines the requirements and needs of future MSDI stakeholders, using a multidisciplinary approach. The paper describes the testing procedures, how to use the interview method, survey and research results. Survey sample was made up of providers and users of marine spatial data in Croatia, considering also future MSDI stakeholders (government and private sector, research institutions and non-governmental organizations). The aim was to investigate the needs for the MSDI implementation, which in Croatia does not exist at the moment. However, results of our research show that the need for this kind of infrastructure is very high and justified. Results and collected information will be the basis for creation of the MSDI geoportal prototype.
\end{abstract}

Keywords: geoportal, Marine Spatial Data Infrastructure (MSDI), Spatial Data Infrastructure (SDI), user needs

\section{INTRODUCTION}

Technology development (cloud computing, volunteered geographic information, big data, data mining, etc.) brings a new dimension of requirements for effective management and the use of spatial data. User needs are changing, as well as the needs of the system itself. Former problems with purchase and transfer of the spatial data are now problems with search ability and optimisation of data. In organized society, spatial data infrastructure (SDI) is becoming the foundation for development and the use of other systems, which are based on the spatial data.

According to the Croatian State Geodetic Administration's (SGA) dictionary, SDI is defined as "a set of technologies, policies, standards, implementation rules, services, human resources and other factors enabling efficient integration, management and maintenance of the sharing of spatial data" [1]. From logical aspect, the SDI structure is made of spatial data, meta data, standards, catalogue and stakeholders cooperation [2]. The SDI serves as a basis for searching and gathering spatial data, and for assessment and use in all sections of society in national administration, commercial and non commercial sector and society itself [3].

Hećimović et al. in [4] deals with different levels of the SDI, such as global, regional, national and local level. There is also corporative and thematic SDI. Nowadays we can even talk about individual SDI's. One example of thematic SDI, which is placed in national and regional level (depends on organisation) is the Marine Spatial Data Infrastructure (MSDI).

Systematic investment in national spatial data infrastructure (NSDI) is a strong suggestion as a part of the e-Croatia 2020 strategy [5]. It leads to a decrease of expenses and increase of quality in services for citizens and the government, especially those who work with spatial data. Croatian NSDI is regulated by the Law of National Spatial Data Infrastructure [6], and by the INfrastructure for SPatial InfoRmation in Europe (INSPIRE Directive) [7].

INSPIRE is an initiative made by the European Commission for establishment of European spatial data infrastructure (ESDI). The Directive that provides legal framework for establishment, supervision and assessment of the INSPIRE came into force in 2007 by the decision and agreement of European parliament and European commission. The purpose was to give support and secure organized and approachable spatial data and information for the countries, which are members of the EU. INSPIRE is based on the EU member states NSDIs.

INSPIRE fosters ESDI establishment, which provides integrated spatial information services to customers. The concept itself is designed in a way to enable users to identify the necessary data sets and allow interoperable access to spatial information from different sources on the European, national, local and regional level [8].

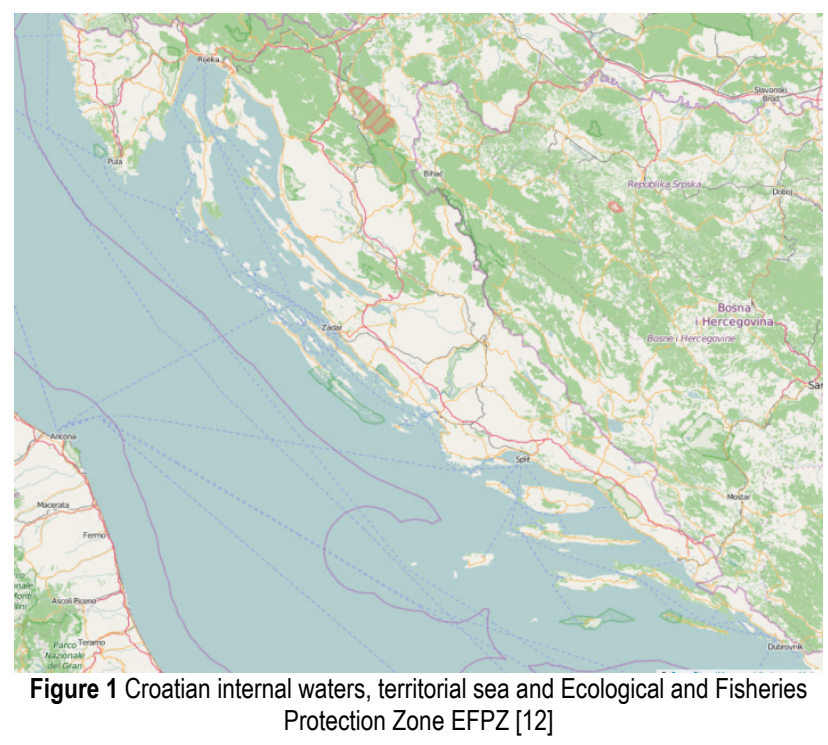

Croatian part of the Adriatic coast is one of the most indented coastlines in the world $[9,10,11]$. The coast is specific because of a big number of islands in the relatively small area $\left(55.349 \mathrm{~km}^{2}\right.$ with internal waters, territorial sea and Ecological and Fisheries Protection Zone EFPZ, Fig. 1) [12]. This area, with a delicate and beautiful nature, carries out many activities as hydro technical construction, touristic development, the development of new industries and maritime activity. 
Activities on the coast and ocean demand constant spatial reorganisation. This is an extremely difficult activity, inefficient and very expensive without established MSDI. NSDI law in the Croatian legislation transposed the INSPIRE Directive. The goal is the NSDI development to enable effective integration and management and as well maintenance of sharing spatial data for the purpose of satisfying the needs at the national and European level. The Croatian NSDI is a part of the ESDI defined by INSPIRE directive, which means that MSDI should be also an integral part of the NSDI.

In the following chapters, a preparatory planning and shaping of MSDI with the goal towards acknowledgement and fitting the needs of future users has been shown. The procedure of examination of users has been displayed, that will help future implementation of MSDI in Croatia. Also, the current state and the distribution of data, organization of stakeholders and preferences of users of spatial marine data and the maritime zone are presented. The results of the survey will be a cornerstone for further implementation of the system. With the development of the MSDI, better and effective management of the coastal and the sea area will be enabled with the consideration of the Croatian sea area.

\section{MARINE SPATIAL DATA INFRASTRUCTURE}

There is a lot of existing research in SDI, which refers mainly to inland data. However, in the recent years, much more has been spoken and written about MSDI, which proves the assertion of the specificity of such data.

One of the significant challenges nowadays is effective marine spatial planning (MSP). Marine spatial data is mainly used as a basis for decision-making [13-17]. By the establishment of an effective MSDI, MSP becomes extended functionality, with benefits to both sides. Fowler et al. in [18] are linking the two concepts in a unified system, in which MSP becomes one of the useful tools within MSDI's.

The need for MSDI is visible in many EU countries and beyond.

Satra Le Bris et al. in [19] describe the development of MSDI in France (SEXTANT) oriented towards the needs of an integrated management and marine environmental protection. Cinnirella et al. in [20] have multidisciplinary approach to MSDI. Using the example of the Mediterranean, whose approach and interests has a large number of countries, emphasizes the need for cooperation and interoperability through unique MSDI within which can be combined from individual MSDI's. Lübker et al. in [21] presented the concept of the German MSDI, which is oriented towards the entry point, geoportal.

International Hydrographic Organization (IHO) is mainly dealing with the issues of marine spatial data and MSDI concept. IHO gathers the national hydrographic institutions from 81 countries, presented in Fig. 2 [22].

IHO as the umbrella organisation for international hydrographic activity contributes to its regulations' approximation to standards of collection and presentation of hydrographic, oceanographic, nautical and other data related to the marine area.

MSDI's are being developed in many countries and have a common goal to establish the infrastructure, which facilitates decision making and management of the marine and coastal environment. A large number of coastal states are investigating various approaches to better manage their areas of jurisdiction, often using technology or tools for spatial data management [23]. Evidently, there is a need for better and more comprehensive way of linking various initiatives, offering a better understanding of the need to connect the marine and coastal environment. These findings provide further support to the claim that the MSDI cannot and should not develop in isolation from the broader national SDI of any jurisdiction [24, 25].

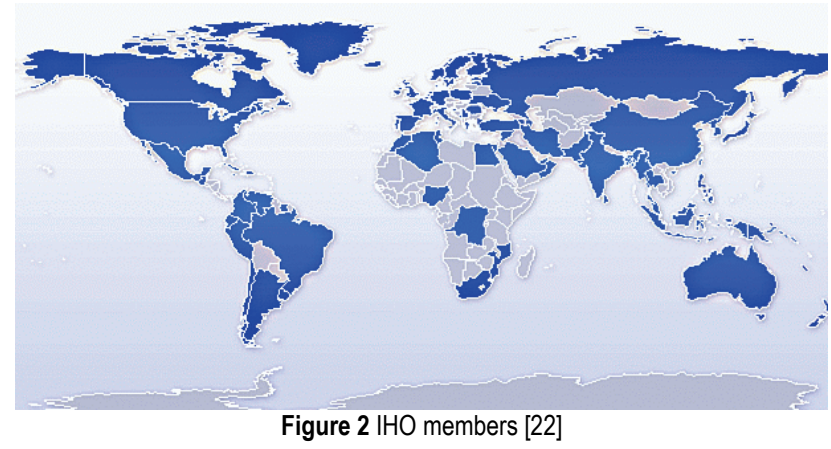

MSDI establishment (with easily accessible and up to date spatial data) with identified responsible stakeholders provides adequate protection of the maritime domain. MSDI is the beginning and the basis of effective utilisation of the coast and the marine economic potential. Development of Croatian MSDI is directly associated with the INSPIRE directive, through regulations at national and regional level. According to the time frame for the establishment of INSPIRE in Croatia [26] and in accordance with the Law of NSDI, all of the data should be harmonised and available until 21 October 2020. The Hydrographic Activity Act [27] in Article 15 defines Hydrographic Institute of the Republic of Croatia (HIRC) as the competent institution for the establishment of the Hydrographic Information System (HIS), which consists of MSDI and maritime cadastre. According to this Act, HIS is defined as "Integrated Spatial Information System, which is conducted on the systematic collection of data by performing hydrographic activities, products and exchange information relevant to the safety of navigation, defence, environment protecting and the marine resources exploitation."

\subsection{Stakeholders Needs during the Establishment of Infrastructure for Marine Spatial Data and in the Republic of Croatia}

Result and "face" of the SDI establishment is the geoportal development as an infrastructure access point. It is a platform used by producers and users of spatial data. According to computer engineering, development application as a geoportal has an increasing emphasis on communication with customers in certain phases of the development cycle. Also the communication of individual organisations and professionals involved in the provision of data is important for the development and use of geoportal. In the development of prototype of MSDI geoportal all, the latest methods of computer engineering and data collected by surveying future users will be used. 
This system requires rapid modelling, and evaluation of adaptive prototypes, which provide quality testing system.

\section{SUPPORT FOR ESTABLISHING THE MSDI IN CROATIA}

Due to the high economic value of coastal and marine areas, their activities and the social value of the zone for the quality of life, coastal zone management is a key component of the socio-economic framework and development of most maritime countries [28]. The coastal region is exposed to natural disasters, which may come from the sea. Also global warming may cause a rise in sea level, which is reflected on the rights, restrictions and responsibilities. Therefore, it is very important to have an accurate and complete source of spatial data and related services, to enable the development planning of coastal areas, and timely disaster management [25].

\subsection{Methodology of Research}

Modern society requires a multidisciplinary approach to research, so we used the interview and survey, which complement each other, to study current and future MSDI users. This scientific method is used in the humanities. The research identified shortcomings of the interview: inefficiency and time ineffectiveness, and the disadvantages of the survey: the subjectivity of respondents, weak response, lack of understanding of issues and the inability to give more information to the questionnaire.

The combination of the selected method has achieved profitability in a relatively short period for the implementation of the survey and the achievement of desired results [29], [30]. The study began with a test version of the questionnaire, which was finally formed and refined suggestions obtained from interviews with five selected experts, who use marine spatial data in their work. According to the test version, the questionnaire formed the final version for a larger sample size, and this method has proved useful in the survey. Using the method of personal and telephone interviews, we obtained valuable information about the needs and habits of future MSDI data providers and users.

Using the method of the survey, we avoided the respondent's bias and covered the broad range of the MSDI viewpoints. During survey presentation respondents access the combined method $[31,32]$, in order to obtain a better response rate and have a better insight into the situation.

Survey itself does not provide a full understanding of the questions by respondents. Sometimes, information gathering often does not seem possible to standardize with rigid form of classic survey [29]. Therefore, the selected technique was a semi-structured interview [33], which offers respondents a questionnaire that they filled in the background of the interview. Data obtained by survey enabled enrichment of the information that was gathered in the interview based on comments of respondents during and after filling out the questionnaire.

\subsection{Research of Users' Needs}

The questionnaire was conducted by Google Forms, which offers the possibility of carrying out with a high degree of interaction [34], [35]. The survey was held in October and November 2014. The collected data are stored in a separate document in accordance with the functions of the web application. Analysis and visualization of data was done with the software Statistical Package for the Social Sciences (SPSS) [36] and Google Forms. We added notes and comments to the collected data recorded through interviews with users. Although questionnaires have been sent to selected respondents, a combined degree of anonymity has been applied (data processing does not record personal data, including the name and personal data of the respondents, and did not influence the processing of the survey results).

\subsubsection{Sample Compilation}

Using the face-to-face interview method [37] with the five chosen experts, who have many years of experience in working with marine spatial data, an experimental questionnaire has been generated. The experts were chosen to represent the institutions and areas of giving and using Marine spatial data (HIRC, Institute of Oceanography and Fisheries, Faculty of Civil Engineering, Architecture and Geodesy and Faculty of Economics, all in Split) in MSDI. The questionnaire was tested and adjusted for further research. In that phase the respondent sample has been made for the second phase of survey, the participants of the MSDI have been identified, as well as the data frame, which has been fulfilled in the second phase.

After the questionnaire was finalised, the survey was carried out with 72 participants. The sample consists of people from:

$\checkmark$ Government (Ministry of Maritime Affairs, Transport and Infrastructure, Ministry of Defence, Ministry of Tourism, Ministry of Environmental and Nature Protection, Ministry of Construction and Physical Planning),

$\checkmark$ State administration (State Geodetic Administration, National Protection and Rescue Directorate, Meteorological and Hydrological Service) and other administrative divisions of Croatia (Cities of Split, Rijeka and Dubrovnik),

$\checkmark$ Scientific institutions (HIRC, Institute of Oceanography and Fisheries, Institute for Marine and Coastal Research),

$\checkmark$ Academy (Faculty of Civil Engineering University of Zagreb, Split, Rijeka and Osijek, University Departments of Marine Study, Faculty of Maritime Studies),

$\checkmark$ Private companies (Safege, Akvadukt, Pomorski objekti, Obala and others),

$\checkmark$ Non-government associations (National Protection and Rescue, Croatian Geological Institute, World Association for the preservation and protection of the sea, rivers and lakes, The Croatian Mountain Rescue Service, Scuba center, Sunce Association for Nature, Environment and Sustainable Development).

$\checkmark$ Others (divers, fisherman, sailor and maritime trainer) [38].

During sample compilation, the focus was set on the experts, who already used marine spatial data in their everyday work and stakeholders as they are relevant to give 
the information about the development of MSDI. Collected data has shown the problems of distribution of such data and it should provide the development of the MSDI. That allows the users to use the geospatial information as "complete data" and gives the advantage to the flexible data sharing. Data from this research is also used in [38] for data themes priority ranking.

The response rate was $100 \%$ because of combined method. In the moments when the sample respondents were not reachable, the suitable replacement was found.

\subsubsection{Making of Questionnaire}

Final version of the questionnaire was made in Google Form application, as well as in the Microsoft Word document for users who did not have access to the internet. Word documents, which were filled in, were later manually entered into Google Form application. View of the interface is shown in Fig. 3. Time given for filling in the questionnaire was 10 minutes.

In order to describe things, processes and appearance in this research, two types of variables were used, dependent and independent variables. Dependent variables stand in the centre of the research, describing problems of the research and they are the most important ones.

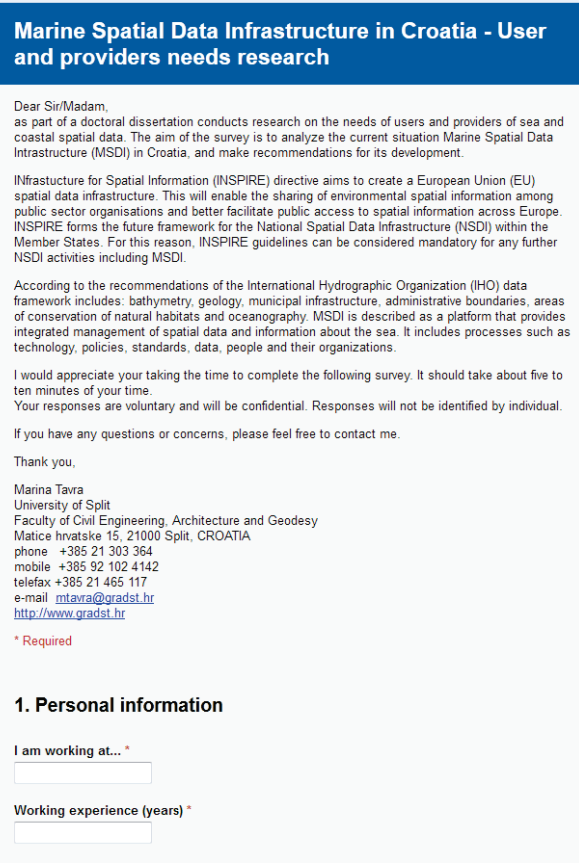

Figure 3 View of the interface

Independent variables used in the research are position of work, years of work experience, function of the organization where the respondent works, type of the platform where he/she manipulates with the spatial data. Dependent variables refer to the questions which are the subject of this research, those questions refer to data bases, availability and purchasing of the data, level of awareness for initiatives on topics like marine spatial data [39, 35].

\subsection{Results}

Final questionnaire has 32 questions, grouped in 5 sections: $\checkmark$ General information (refers to general questions about the respondent, in which organization he/she works and for how long),

$\checkmark$ Organization (refers to the questions about the organization, in which the respondent works or belongs, what is their role, how they collect data, and which work platform they use),

$\checkmark$ Data [third group of questions refer to information about the definition of current spatial data frame, their refreshing and availability. This section is organized in a way to ask questions based on the former data frame, such as: Which information about sea does your organization give, without any reimbursement? Under those questions, there are themes, which the respondents can choose (more than one) and add some other themes about data],

$\checkmark$ Distribution of the data (refers to the questions about purchasing spatial data from other stakeholders),

$\checkmark \quad$ MSDI and geoportals (refers to the level of awareness of the user about organized systems of data and initiatives on the EU level, as well as the components of the SDI for geoportals).

At the end of the questionnaire, the respondents were able to write their own opinion and observations about questionnaire, and the MSDI.

\subsubsection{Level of Awareness of the Respondent about the Initiatives and Concept of MSDI}

"Society as a whole is gaining more and more interest in SDI and public awareness about SDI is increasing" [4].

Questionnaire sample consisted of the experts who use marine spatial data in their everyday work. It implies that these respondents use terms related to spatial data in their everyday work, and because of that an unexpected fact was received, more than $50 \%$ of the respondents had never heard of INSPIRE before they took the questionnaire, which can be seen in Tab. 1. Also, nearly $70 \%$ of the respondents have never heard about SDI or MSDI. And that proves the hypothesis from the introduction. On the other side, most of the respondents $(87 \%)$ agree that the change is needed through the distribution of the data via geoportals, which is one of the components of MSDI.

Marine spatial data is either unavailable or partially available to public and to the experts, for example the marine cadastre as a part of HIS has not yet been established. Therefore public and experts must be educated and aware about the MSDI and INSPIRE.

The rest of the questions, which relate to the level of awareness of the respondents about the concept, are in Tab. 2. This table shows that most of the respondents $50 \%$ know of NSDI concept, with the help from the sector for SDI and work sections of NSDI.

Great number of the respondents $(80 \%)$ already uses the geoportals, and many of them would like to see new services.

Answer the question: "Which services of the geoportals would you like to use?" It is shown as a graph in Fig. 4. Almost 60 respondents want to use geoportal to download data in GIS formats.

Most of the geoportals do not give that opportunity, but with the development of the marine spatial data geoportals 
many possibilities are created, such as possibility of analysis and processing of the data on the Web application, and there is a possibility for downloading those data.
Because of that, it is very important to establish the levels of user rights through a licensing system.

Table 1 Level of awareness about the INSPIRE directive, MSDI and geoportals by groups of users

\begin{tabular}{|c|c|c|c|c|c|c|}
\hline \multirow{2}{*}{$\begin{array}{c}\text { Group of users } \\
\text { Answer }\end{array}$} & \multicolumn{2}{|c|}{$\begin{array}{l}\text { Have you heard of INSPIRE } \\
\text { directive before this survey? }\end{array}$} & \multicolumn{2}{|c|}{$\begin{array}{l}\text { Do you think there is a need } \\
\text { for MSDI geoportal? }\end{array}$} & \multicolumn{2}{|c|}{$\begin{array}{c}\text { Have you heard of MSDI concept } \\
\text { before this survey? }\end{array}$} \\
\hline & Yes & No & Yes & I don't know & Yes & No \\
\hline Academy & 4 & 9 & 10 & 3 & 4 & 9 \\
\hline Non-government organizations & 2 & 3 & 4 & 0 & 0 & 5 \\
\hline Government & 8 & 6 & 12 & 2 & 3 & 11 \\
\hline Others & 2 & 7 & 8 & 1 & 4 & 5 \\
\hline Private sector & 2 & 8 & 9 & 1 & 3 & 7 \\
\hline Institutions & 7 & 7 & 12 & 2 & 5 & 9 \\
\hline State administration & 6 & 1 & 6 & 0 & 4 & 2 \\
\hline Final & 31 & 41 & 61 & 9 & 23 & 48 \\
\hline Final (\%) & 43 & 57 & 87 & 13 & 32 & 68 \\
\hline
\end{tabular}

Table 2 Level of awareness about the NSDI concept, MSDI and current geoportals usage

\begin{tabular}{|c|c|c|c|}
\hline Question & Yes (\%) & No (\%) & Maybe (\%) \\
\hline $\begin{array}{c}\text { Have you before this survey } \\
\text { met with the concept of } \\
\text { NSDI? }\end{array}$ & 57 & 43 & - \\
\hline $\begin{array}{c}\text { Do you consider yourself a } \\
\text { MSDI stakeholder? }\end{array}$ & 37.5 & 12.5 & 50 \\
\hline $\begin{array}{c}\text { Do you think that the MSDI } \\
\text { in your country is needed? }\end{array}$ & 80.5 & - & 19.5 \\
\hline $\begin{array}{c}\text { Do you want to join MSDI } \\
\text { and exchange data with } \\
\text { other users? }\end{array}$ & 75 & - & 25 \\
\hline $\begin{array}{c}\text { Do you usually use the } \\
\text { geoportals at work? }\end{array}$ & 79 & 12.5 & 8.5 \\
\hline
\end{tabular}

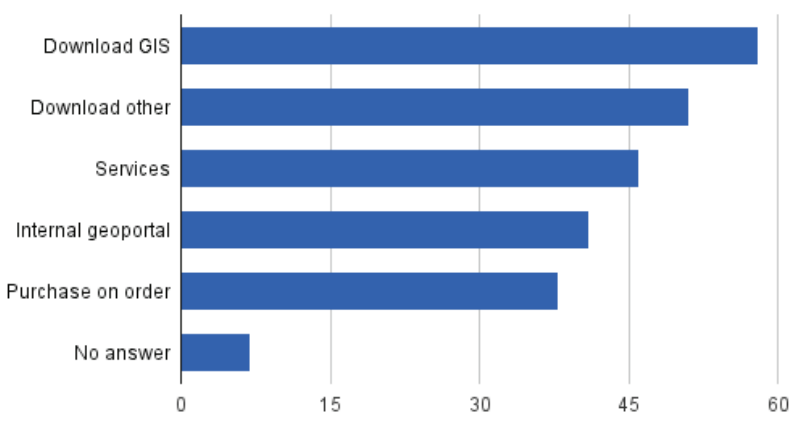

Figure 4 Preferred services of a geoportal by number of respondents

According to [28] for the establishment of reliable and upgradable system, it is necessary to systematically approach the examination of the users. This kind of approach emphasizes the importance of geoportal as an approachable point for exchange and review of information, as well as the system organization itself in order to transfer the data through the geoportal fast and effectively.

\subsubsection{Distribution and Analysis of Data Availability}

For the purpose of future MSDI geoportal, it is necessary to collect information about data distribution. The focus of the problem is the availability of marine spatial data in Croatia and the ways of supplying the data. According to the survey, $47.9 \%$ of respondents collect data on an official request, $32.2 \%$ take the public available data, and $19.8 \%$ of its data are buying in the market.
Assessment of the data availability has been according to two criteria: general assessment of the data availability and a time period needed for the data collecting.

According to the criteria, it is visible that both users and providers of data have problems with spatial data delivery (over 50\%). According to answers it is visible that most respondents think that there is no defined procedure of data collecting, which confirms the need for the geoportal as organized system for display and exchange of spatial data. In the interview with experts on this question, as additional comments, communication problems in the institutions were mentioned, such as responsibility dispersion, corruption and non-existence of clear rules.

These problems directly affect the time component of collecting some data. Only $16.7 \%$ of respondents mostly get the requested data in a week period, the rest get their data within a month, and even longer.

\section{CONCLUSIONS}

The need for better management of the marine environment requires development of MSDI. Countries and different state jurisdictions are improving their marine management through the improvement of accessibility and availability of marine spatial data. Current marine administrations include resources and risk management, which involve marine industries and marine protected areas.

The aim of this research was to gather the relevant information from the providers and users of marine spatial data as a basis for further modelling and development of MSDI in Croatia. For this purpose, we developed a survey that was complemented by interviews with relevant MSDI stakeholders.

The survey questioned a wide range of existing and future stakeholders. It defines the requisite and possibilities for data and services, which will help modelling and establishing the future MSDI. Based on the results of the research, we can conclude that in Croatia the need is evident for an organized system of marine data management. Current distribution of the marine spatial data is not systematic so far. It is very slow, nontransparent and very expensive for a large number of users and stakeholders. It is also important to note that marine spatial data is more expensive than inland spatial data, 
because of the surveying methods and ways of data gathering.

Most of the respondents $(80 \%)$ thought that the establishment of the MSDI is necessary. Many of the respondents $(79 \%)$ are already using geoportals as a source of the spatial data. Large number of direct and indirect stakeholders of the future MSDI, $57 \%$ of them, is not familiar with the standards in this area, or the concept of MSDI. Most of the respondents have positive attitude to development of the MSDI in Croatia and development of the geoportal. According to all mentioned the need for MSDI is justified. Further development should be focused on the content and the model of MSDI, as well as the specific implementation.

Survey and methodology in this research is a part of the MSDI model establishment process as described by the INSPIRE guidelines. The goal of the survey was to explore among users the purpose of the future content, current state and the distribution of maritime spatial data. Questionnaire wanted to try out the necessity of the model production, to enhance the process of the data selection and distribution. The collected results should contribute to the creation of an optimal model concept.

Involving stakeholders in the process of MSDI establishment leads to a more effective system. Stakeholders have a better insight into the situation (user needs, needs of other stakeholders), suggesting their own requirements to avoid future management and other conflicts inside the MSDI.

Future research should be aimed towards addition of content and the MSDI model and moreover, its implementation. Achieving the technological precondition, and according to the user's needs that the survey has gathered the building of MSDI should be based on the European and international guidelines and standards. In further research, we plan to investigate the approaches of effective and seamless connection with the MSDI and the NSDI in a unique spatial model.

\section{Acknowledgements}

The development of this research paper was supported by the scientific project HRZZ-IP-11-2013-7714 "DEMLAS" funded by the Croatian Science Foundation

\section{REFERENCES}

[1] Croatian State Geodetic Administration, Dictionary, http://www.dgu.hr/rjecnik-geodetskih-pojmova/ (10.8.2015)

[2] Cetl, V., MastelićIvić, S., \& Tomić, H. (2009). Improvement of National Spatial Data Infrastructure as a Public Project of Permanent Character. Cartography and Geoinformation, 8(11), 69-83.

[3] Cetl, V., Roić, M., \& Šiško, D. (2004). Towards a Spatial Data Infrastructure in Croatia. Cartography and Geoinformation, 3(3), 37-59.

[4] Hećimović, Ž., Marasović, S., \& Crompvoets, J. (2014) Development of local spatial data infrastructure in Croatia. Journal of Spatial Science, 59(2), 221-234. https://doi.org/10.1080/14498596.2014.908424

[5] Ministry of Public Administration, e-Croatia 2020 strategy. 2015. https://uprava.gov.hr/UserDocsImages//e-Hrvatska// eCroatia\%202020\%20Strategy\%20\%2820.01.2016.\%29.pd $\mathrm{f}(30.4 .2016)$
[6] Constitution of the Republic of Croatia: Law of National Spatial Data Infrastructure (Official Gazette 56/13), 2013.

[7] European Parliament, (2007), Directive 2007/2/EC of the European Parliament and of the Council of 14 March 2007 establishing an Infrastructure for Spatial Information in the European Community (INSPIRE), Official Journal of the European Union, no. 108.

[8] Poslončec-Petrić, V. (2010). Distribution of Spatial Data official cartography in the Republic of Croatia, Doctoral dissertation, Faculty of Geodesy, University of Zagreb.

[9] Duplančić Leder, T., Ujević, T., \& Čala, M. (2004). Coastline Lengths and Areas of Islands in the Croatian Part of the Adriatic Sea Determined from the Topographic Maps at the Scale of $1: 25000$. Geoadria, 9(1), 5-32. https://doi.org/10.15291/geoadria.127

[10] NASA National Aeronautics and Space Administration Visible Earth. A catalogue of NASA images and animations of our home planet. http://visibleearth.nasa.gov/ view.php?id=38396 (11.8.2015)

[11] Leder, N., Barbalić, S., Filipović, V., \& Barbalić, D. (2011). Proposal for Determination of the Republic of Croatia's Coastal Waters According to the Water Framework Directive. $5^{\text {th }}$ Croatian Water Conference with International Participation "Croatian Waters Facing the Challenge of Climate Change" / Opatija, 582-591.

[12] OpenStreetMap. https://www.openstreetmap.org (12.11.2015)

[13] Stelzenmüller, V., Lee, J., South, A., Foden, J., \& Rogers, S. I. (2013). Practical tools to support marine spatial planning: a review and some prototype tools. Marine Policy, 38, 214227. https://doi.org/10.1016/..marpol.2012.05.038

[14] Redfern, J. V., McKenna, M. F., Moore, T. J., Calambokidis, J., Deangelis, M. L., Becker, E. A., Barlow, J., Forney, K. A., Fiedler, P. C., \& Chivers, S. J. (2013). Assessing the risk of ships striking large whales in marine spatial planning. Conservation Biology, 27(2), 292-302. https://doi.org/10.1111/cobi.12029

[15] Shucksmith, R. J. \& Kelly, C. (2014). Data collection and mapping-Principles, processes and application in marine spatial planning. Marine Policy, 50, 27-33. https://doi.org/10.1016/j.marpol.2014.05.012

[16] McLain, R., Poe, M., Biedenweg, K., Cerveny, L., Besser, D., \& Blahna, D. (2013). Making sense of human ecology mapping: an overview of approaches to integrating sociospatial data into environmental planning. Human Ecology, 41(5), 651-665. https://doi.org/10.1007/s10745-013-9573-0

[17] Collie, J. S., Beck, M. W., Craig, B., Essington, T. E., Fluharty, D., Rice, J., \& Sanchirico, J. N. (2013). Marine spatial planning in practice. Estuarine, Coastal and Shelf Science, 117, 1-11 https://doi.org/10.1016/j.ecss.2012.11.010

[18] Fowler, C., Smith, B., \& Stein, D. Building a marine spatial data infrastructure to support marine spatial planning in US waters. GISLANDS, http://www.gislands.org (22.5.2016)

[19] Satra Le Bris, C., Treguer, M., Meillon, J., \& Quimbert, E. (2014). Sextant: A spatial data infrastructure for marine environments. In INSPIRE (Infrastructure for Spatial Information in the European Community), conference 2014 INSPIRE for good governance, 16-20 June 2014, Aalborg University, Denmark.

[20] Cinnirella, S., March, D., O'Higgins, T., Murciano, C., Sardà, R., Albaigés, J., \& Pirrone, N. (2012). A multidisciplinary spatial data infrastructure for the Mediterranean to support the implementation of the Marine Strategy Framework Directive. International Journal of Spatial Data Infrastructures Research, 7, 323-351.

[21] Lübker, T., Hübner, P., Rüh, C., \& Korduan, P. (2013). Facilitating the Exchange of Marine Geospatial Data through the Marine Data Infrastructure for Germany (MDI-DE). 
http://mdi-de.hosted-by-kfki.baw.de/268 proceeding. pdf (23.5.2016)

[22] International Hydrographic Organization https://www.iho.int (23.5.2016)

[23] Strain, L., Rajabifard, A., \& Williamson, I. (2006). Spatial Data Infrastructure and Marine Administration. Journal of Marine Policy, 30, 431-444 https://doi.org/10.1016/..marpol.2005.03.005

[24] Duplančić Leder, T. \& Leder, N. (2009). Sea SDI as an Integral Part of the NSDI. $1^{\text {st }}$ Croatian NSDI and INSPIRE Day and the Cartography and Geoinformation Conference / Zagreb, 39-40.

[25] Vaez, S. (2010). Building a Seamless SDI Model for Land and Marine, Dissertation, University of Melbourne, Australia Environments, Australia.

[26] National Spatial Data Infrastructure in the Republic of Croatia. http://www.nipp.hr (12. 8. 2015)

[27] The Hydrographic Activity Act (OG 71/14), 2014.

[28] Tavra, M. \& Cetl, V. (2013). MSDI and Geoportals in Selected European States: A Comparative Analysis. Proceedings of SDI days 2013, 92-97.

[29] Bird, D. \& Dominey-Howes, D. (2008). Testing the use of a 'questionnaire survey instrument to investigate public perceptions of tsunami hazard and risk in Sydney, Australia. Natural Hazards. 45(1), 99-122. https://doi.org/10.1007/s11069-007-9172-8

[30] Muto, M., Tsunoda, T., \& Kumasaka, F. (2010). Development of Marine Spatial Data Infrastructure in Japan. Japan Hydrographic Association. https://www.yumpu.com/en/document/view/22106402/deve lopment-of-marine-spatial-data-infrastructure-in-japan (12.12.2015)

[31] Bradburn, N. M., Sudman, S., \& Wansink, B. (2004). Asking questions: the definitive guide to questionnaire design-for market research, political polls, and social and health questionnaires. John Wiley \& Sons.

[32] Verfaillie, E., De Wit, B., Kellens, W., Maddens, R., Van de Weghe, N., Vanopbroeke, V., \& De Maeyer, P. (2012). A questionnaire to evaluate the GI job market in Flanders: first findings. The $8^{\text {th }}$ European GIS Education Seminar 6-9 September, 2012 GIS-education: Where are the boundaries? 2012, September, p 73.

[33] Sebake, M. D. \& Coetzee, S. (2013). Address Data Sharing: Organizational Motivators and Barriers and their Implications for the South African Spatial Data Infrastructure. International Journal of Spatial Data Infrastructures Research, 8, 1-20.

[34] Google Forms, About https://www.google.com/forms/about/ (5.12.2015)

[35] Wright, K. B. (2005). Researching Internet-based populations: Advantages and disadvantages of online survey research, online questionnaire authoring software packages, and web survey services. Journal of Computer-Mediated Communication, 10(3), 00-00. https://doi.org/10.1111/j.1083-6101.2005.tb00259.x

[36] Green, S. B. \& Salkind, N. J. (2010). Using SPSS for Windows and Macintosh: Analyzing and understanding data, Prentice Hall Press.

[37] Holbrook, A. L., Green, M. C., \& Krosnick, J. A. (2003). Telephone versus face-to-face interviewing of national probability samples with long questionnaires: Comparisons of respondent satisficing and social desirability response bias. Public Opinion Quarterly, 67(1), 79-125. https://doi.org/10.1086/346010

[38] Tavra, M.; Jajac, N. Cetl, V. (2017). Marine Spatial Data Infrastructure Development Framework: Croatia Case Study. ISPRS International Journal of Geo-Information, 6(4), 117. https://doi.org/10.3390/ijgi6040117

[39] Examples, Your Dictionary http://examples.yourdictionary.com (6.12.2015)

\section{Contact information:}

Marina TAVRA, mag. ing. geod. etgeoinf., Research assistant University of Split,

Faculty of Civil Engineering, Architecture and Geodesy Maticehrvatske 15, 21000 Split, Croatia

mtavra@gradst.hr

Tea DUPLANČIĆ LEDER, PhD, Associate professor

University of Split,

Faculty of Civil Engineering, Architecture and Geodesy

Maticehrvatske 15, 21000 Split, Croatia

tleder@gradst.hr

Vlado CETL, PhD, Associate Professor

University of Zagreb

Faculty of Geodesy

Kačićeva 26, 10000 Zagreb, Croatia

vcetl@geof.hr 